\title{
What Drives Commodity \\ Price Booms and Busts?
}

David S. J acks and Martin Stuemer

Federal Reserve Bank of Dallas

Research Department

Working Paper 1614 


\title{
What drives commodity price booms and busts?*
}

\author{
David S. Jacks (Simon Fraser University and NBER) \\ Martin Stuermer (Federal Reserve Bank of Dallas, Research Department)
}

November 2016

\begin{abstract}
What drives commodity price booms and busts? We provide evidence on the dynamic effects of commodity demand shocks, commodity supply shocks, and inventory demand shocks on real commodity prices. In particular, we analyze a new data set of price and production levels for 12 agricultural, metal, and soft commodities from 1870 to 2013. We identify differences in the type of shock driving prices of the various types of commodities and relate these differences to commodity types which reflect differences in long-run elasticities of supply and demand. Our results show that demand shocks strongly dominate supply shocks.

\footnotetext{
* The views in this paper are those of the authors and do not necessarily reflect the views of the Federal Reserve Bank of Dallas or the Federal Reserve System. Jacks gratefully acknowledges the Social Science and Humanities Research Council of Canada for research support. We are grateful for comments and suggestions from participants at the Summer Meeting of the Association of Environmental and Resource Economists, at the Bank of Canada and Federal Reserve Bank of Dallas joint conference on commodity price cycles, at the Norges Bank/CAMP workshop, and at seminars at the Bundesbank and the European Central Bank.
} 
JEL classification: E30, Q31, Q33, N50

Keywords: Commodity prices, natural resources, structural VAR 1. Introduction

Understanding the drivers of commodity price booms and busts is of first-order importance for the global economy. A significant portion of incomes and welfare of both commodity-consuming and commodity-producing nations hinges upon these prices (Bernanke, 2006; IMF, 2012). They also vitally affect the distribution of incomes within particular nations as the ownership of natural resources varies widely. What is more, the long-run drivers of commodity prices also have serious implications for the formation and persistence of both growth-enhancing and growth-detracting institutions (van der Ploeg, 2011). But for all this, outside spectators - whether they are academics, the general public, the investment community, or policy-makers_-remain seriously divided in assigning the importance of the various forces in the determination of commodity price booms and busts.

The recent history of commodity prices is indicative of this situation. Rising from multidecade lows in the late 1990s, real commodity prices rose for the next 10 years, culminating in the price spike of 2008 when they stood over three times their level in 1998 (Jacks, 2013). All along the way, observers battled it out, variously pointing to the respective roles of fundamentals versus speculation in driving real commodity prices to such heights (Irwin et al., 2009). Recent developments in the opposite direction —-with real commodity prices having shed roughly 50\% of their value in the past three years—-have likewise generated much heat, but not so much light. Yet regardless of any particular commenter's take on the ultimate driver of commodity price booms and busts, none have doubted the question’s importance.

At the same time, a fairly large academic literature has developed which follows the work of Kilian (2009) in evaluating the sources of commodity price dynamics. Here, structural vector 
autoregressive models are used to decompose changes in commodity prices into different types of shocks. Identification is made possible by assigning short-run (or sign) restrictions based on assumptions primarily—but not exclusively—related to inelastic short-run demand and supply curves. The upshot of much of this work has been a reversal in our understanding of the shortrun determinants of commodity prices. That is, while an earlier literature implicated supply shocks as a chief source of fluctuations in commodity prices, this more recent literature finds that demand shocks are the major source of fluctuations in prices for crude oil (Kilian, 2009). ${ }^{1}$

Our contribution to this literature comes in being the first in providing evidence on the drivers of real commodity prices over a broader set of commodities and over a broader span of time. To this end, we assemble a new data set on the level of prices and production for 12 commodities, spanning the categories of agricultural, metal, and soft commodities from 1870 to 2013. In marked contrast to this literature which generally uses monthly data over years or perhaps decades, we use annual data over the past 165 years. This context makes it hard for us to rationalize a steep—-that is, an inelastic — long-run supply curve which is one of the basic identifying assumptions of SVARs based on short-run (or sign) restrictions.

Instead, we build on Stuermer's (2016) identification scheme which is based on the idea that booms in real commodity prices induced by increases in global demand for commodities set in motion two processes: investment in new productive capacity and productivity-enhancing technological innovation. This allows us to specify three orthogonal shocks to real commodity prices based on long-run restrictions, namely a commodity demand shock, a commodity supply shock, and an inventory or commodity-specific demand shock. Here, we emphasize that these shocks are specifically related to commodity markets and are not to be confused with the aggregate demand and aggregate supply shocks used in much of the macroeconomic literature.

\footnotetext{
${ }^{1}$ See Carter et al. (2011) for a detailed summary of theories on fluctuations in commodity markets.
} 
In particular, we assume that a commodity demand shock, representing an unexpected expansion in global GDP, potentially has long-run effects not only on global GDP itself but also on the production of individual commodities. We also assume that a commodity supply shock, representing a disruption in the physical production of a particular commodity, leads only to a potential long-run effect on that commodity's production but not on global GDP. Finally, we interpret the residual term, capturing all remaining uncorrelated shocks, as an inventory or commodity-specific demand shock. This term is assumed to have no long-run effects on either global GDP or a commodity’s global production. At its heart, this shock can be interpreted as capturing unexpected changes in inventory demand due to underlying changes in expectations. In combination, this identification scheme allows us to leave all short-run relationships unrestricted.

Based on the structural VAR, we derive historical decompositions for each of the relevant commodities. The historical decomposition shows the contribution of each shock in driving booms and busts in each real commodity price series over time. It serves to quantify the independent contribution of the three shocks to the deviation of each commodity price from its base projection after accounting for long-run trends in real commodity prices. Our results indicate that commodity demand shocks and inventory or commodity-specific demand shocks rather than commodity supply shocks are the primary drivers of real commodity price booms and busts. Additionally, we find that the quantitative contribution of commodity demand shocks to prices varies across the different commodities. At the same time, commodity demand shocks exhibit a common pattern with respect to their timing across all commodity markets. Third, inventory or commodity-specific demand shocks are an important driver in commodity price booms and busts for most of our agricultural and soft commodities. Finally, commodity supply 
shocks play some role in explaining fluctuations for particular commodities, but in the main, their influence on real commodity prices is limited in its impact and transitory in nature.

The rest of the paper proceeds as follows. Section 2 sets out the underlying data while Section 3 outlines the methodology related to structural vector auto-regressions. Section 4 provides the results on the contribution of various shocks on commodity price dynamics. Section 5 concludes.

\section{New Data on Long-Run Prices and Production}

The data used in this study represent the end result of a number of selection criteria. First, prices were drawn for all consistently-defined commodities with at least 5 billion US dollars of production in 2011 (for further discussion, see Jacks, 2013). The individual price series are expressed in US dollars and deflated by the US Consumer Price Index underlying Officer (2012), supplemented by updates taken from the U.S. Bureau of Labor Statistics.

Next, these prices were matched with production data for those commodities for which there is evidence of a high degree of homogeneity in the traded product (or at least, in its reference price), evidence of an integrated world market, and no evidence of significant structural changes in their marketing or use over time. ${ }^{2}$ All told, this paper then considers the evidence on 12 individual commodity price series (barley, coffee, copper, corn, cotton, cottonseed, lead, rice, rye, sugar, tin, zinc) which are drawn from three product categoriesgrains, metals, and soft commodities. Finally, global GDP data is based on Maddison (2010) and extensions from Stuermer (2016).

\footnotetext{
2 This last requirement precludes a consideration of natural gas and petroleum in light of the radical changes in the industrial organization of these sectors throughout the $20^{\text {th }}$ century (Yergin, 1991).
} 
Figure 1 documents the evolution of global GDP in percentage terms from 1870 to 2013 while Figures 2 through 4 document the evolution of real commodity prices and production from various start dates to 2013. Appendix I details the sources for the individual series.

\section{Structural Vector Autoregression}

We follow Kilian (2009) and subsequent authors in applying a structural vector autoregressive model to decompose changes in commodity prices into different types of shocks. In marked contrast to this literature which generally uses monthly data over decades, we use annual data over the past 145 years. This context makes it hard for us to rationalize an inelasticthat is, steep-supply curve, which is one of the basic identifying assumptions of SVARs based on short-run (or sign) restrictions. Instead, we build on Stuermer's (2016) identification scheme which allows us to specify three orthogonal shocks to real commodity prices based on long-run restrictions, namely a commodity demand shock, a commodity supply shock, and commodityspecific inventory or other demand shock.

\section{A. Identification}

The identification scheme is based on the idea that increases in real commodity prices induced by increases in global demand for commodities set in motion two processes: investment in new productive capacity and productivity-enhancing technological innovation. This idea has gained considerable traction in the resource economics literature of late. For example, Anderson et al. (2014) show how global shocks to the demand for crude oil have induced new drilling in the United States in the last few years. Likewise, Stuermer and Schwerhoff $(2013,2015)$ provide stylized facts on R\&D in the extractive sector and construct a growth model with a non- 
renewable resource stock which may be periodically augmented due to R\&D investment in extraction technologies. A somewhat analogous argument has been made by earlier contributions to the literature on growth models and natural resources (Aghion and Howitt, 1998; Groth, 2007). This work basically argues that increases in factor productivity drive up total output of an economy and, thereby, productivity in the use of natural resources. Stuermer (2016) is the first to build on these insights for the purpose of identifying different shocks to commodity prices based on long-run restrictions.

We use these restrictions in the same way to identify three mutually uncorrelated shocks to real commodity prices. First, we assume that a commodity demand shock potentially has persistent effects on both global GDP and global production of the respective commodity. This is consistent with the logic outlined above in which unexpected changes in global GDP endogenously affect the extensive and intensive margins of commodity production, but only in the long run.

Furthermore, we assume that a commodity supply shock potentially has a long-run effect on global production of the respective commodity, but no long-run effect on global GDP. ${ }^{3}$ Thus, our commodity supply shock captures unexpected disruptions in global production of a commodity due to cartel action, inter- or intra-state conflict, labor action, weather, or the like. It might also include the unexpected opening of new mines in the case of metals or minerals or the conversion of land to the cultivation of a specific crop in the case of agricultural or soft commodities. These events are allowed to affect global GDP for quite some time as we use annual data, but ultimately, they will not affect global GDP in the long run. The reasoning here is that short-run disruptions to production are eventually eased through conservation and

\footnotetext{
${ }^{3}$ This suggests one reason why we do not consider petroleum and other energy products in this paper.
} 
substitution while new mineral reserves eventually get depleted and/or arable land might eventually switch back to the cultivation of agricultural or soft commodities.

Finally, the inventory or commodity-specific demand shock is a residual which captures all shocks that are not correlated with either the commodity demand shocks or the commodity supply shocks described above. We interpret this residual shock along the lines of Stuermer (2016) as a shock to the demand for storage of the respective commodity which potentially stems from three different sources: 1) government stocking programs, 2) commodity producers with market power who increase their inventories in an attempt to manipulate prices, and 3) shifts in the expectations of downstream commodity-processing industries or midstream commoditytrading firms about the future balance of supply and demand (on the last point, see Kilian, 2009). ${ }^{4}$

We assume that price changes due to this inventory or commodity-specific demand shock exhibits transitory but not long-run effects on global production of the respective commodities. They thereby only affect capacity utilization in the commodity-producing sector, but not longrun investment decisions. We consider this assumption to be plausible, in that permanently expanding production capacity generally exhibits significant fixed costs and takes many yearsand in some instances, decades—-to come on-line (Radetzki, 2008; Wellmer, 1992). We furthermore assume that this type of shock does not have any potential long-run effects on global GDP. Certainly, an increase in commodity prices driven by shocks to inventory demand decreases the income of consumers in importing countries. At the same time, it increases the income of consumers in exporting countries so that there may be no net effect on global GDP via aggregate demand. For instance, Rasmussen and Roitman (2011) show on a global scale that even oil price shocks only exhibit small and transitory negative effects for the majority of

\footnotetext{
${ }^{4}$ We are unable to directly include a proxy for inventories in this study due to data constraints.
} 
countries. Table 1 summarizes our assumptions on the persistent and transitory effects of the three orthogonal shocks discussed above.

\section{B. Econometric model}

Formally, we use a structural vector autoregressive system with long-run restrictions for each commodity market. The econometric model includes three endogenous variables, notably the percentage change in global GDP $(\Delta Y)$, the percentage change in global production of the respective commodity $\left(\Delta Q_{i}\right)$, and the log of the real price of the respective commodity $\left(\ln \left(P_{i}\right)\right)$. The matrix of deterministic terms $D$ consists of a constant and a linear trend. These deterministic terms are designed to account for long-run trends in the costs of production, the costs of trade, and the intensity of use of the respective commodity in the global economy. ${ }^{5}$

We also add annual fixed effects for World War I and the three subsequent years after its conclusion (that is, from 1914 to 1921) as well as World War II and the three subsequent years after its conclusion (that is, from 1939 to 1948). These fixed effects are meant to control for the fact that world markets for commodities during these time periods were subject to market distortions related to government policy and restrictions to trade related to the nature of the conflicts.

The structural VAR representation is

(1) $A x_{t}=\alpha D_{t}+\beta_{1}^{*} x_{t-1}+\ldots+\beta_{p}^{*} x_{t-p}+B \varepsilon_{t}$,

\footnotetext{
${ }^{5}$ The results presented below are robust to a number of different approaches to the data. First, we have allowed for the possibility of non-linear trends in real commodity prices. De-trended real commodity prices were derived via the Christiano-Fitzgerald asymmetric band-pass filter used in Jacks (2013). No material differences in our results were forthcoming. Second, we have used a shorter sample from 1900 to 2013 to reflect concerns about the quality of data, in particular, that for production in the nineteenth century. Again, the associated results are not qualitatively different than those presented here.
} 
where $x$ is the vector of endogenous variables and $\varepsilon$ is a vector of mutually and serially

uncorrelated structural innovations. The reduced form coefficients are $\beta_{j}=A^{-1} \beta_{j}^{*}$ for $j=1, \ldots$, $p$. The relation to the reduced form residuals is given by $u_{t}=A^{-1} B \varepsilon_{t}$. We impose zero restrictions on the long-run matrix of structural shocks by assuming that it is lower triangular (for technical details, see Stuermer, 2016). This leaves the contemporaneous relationships completely unrestricted. We set the number of lags ( $p$ ) as four for all commodities for the benchmark regressions. We have also run the regressions allowing for a different number of lags across commodities with the number of lags being chosen according to the Akaike Information Criterion. The results remain materially unaffected, and here, we focus on the former set of results for ease of presentation.

\section{Results}

We present results for a set of impulse response functions for and historical decompositions of real commodity prices in the following sub-sections.

\section{A. Impulse Response Functions}

Figures 5 to 7 present the impulse response functions for each commodity. The impulse response functions show how the percentage change in global GDP, the percentage change in global production of the respective commodity, and the log of the respective real commodity price react to a one-standard deviation change in one of the three respective shocks through time. We make use of the accumulated impulse response functions for the shocks to global commodity production and global GDP to illustrate the long-run effects on these variables. One of the 
purposes of this exercise is to ensure that our method produces economically meaningful results. In particular, we expect a priori that:

(1) positive commodity demand shocks are associated with higher real global GDP, generally induce higher global commodity production, and serve to increase real commodity prices;

(2) positive commodity supply shocks have limited effects on real global GDP, generally induce persistently higher global commodity production, and serve to decrease real commodity prices; and

(3) positive inventory or commodity -specific demand shocks have limited effects on real global GDP, generally induce a muted response in global commodity production, and serve to increase real commodity prices.

Cumulatively, the impulse response functions demonstrate that the reaction of real prices to the different types of shocks are either in line with what one would reasonably expect or statistically insignificant. Positive commodity demand shocks and positive inventory or commodity-specific demand shocks both serve to increase real commodity prices while positive commodity supply shocks serve to decrease real commodity prices. On average, the effects of commodity demand shocks are the most persistent, with effects lingering 10 years or more. This is followed by inventory or commodity-specific demand shocks which are slightly less persistent, but with effects that might last up to 10 years in some cases. Finally, the effect of commodity supply shocks is, for the most part, insignificant. However, a few exceptions to this general result are to be found in the sugar and tin markets with effects which persist up to five years. 


\section{B. Historical Decompositions}

The historical decompositions show the contribution of each shock in driving fluctuations in each real commodity price series. They serve to quantify the independent contribution of the three shocks to the deviation of each commodity price from its base projection. Thus, Figures 8 to 10 depict the historical decomposition of booms and busts for each commodity under consideration here. The vertical scales are identical across the three sub-panels such that the figures illustrate the relative importance of a given shock. Another way of intuitively thinking about these historical decompositions is that each of the sub-panels represents a counterfactual simulation of what the real price of a particular commodity would have been if it had only been driven by this particular shock.

For instance, take the case of commodity demand shocks. The collective story which emerges from our figures suggests that although the proportional contribution of the commodity demand shocks naturally varies across the different commodities, their accumulated effects broadly follow the same pattern with respect to timing across the 12 commodities. Thus, commodity demand shocks affect real commodity prices to different degrees, but they affect the real commodity prices at the same time. These results then suggest that commodity demand shocks have a common source.

What is more, this interpretation of the accumulated commodity demand shocks is in line with what economic history has to say about fluctuations in global output. Thus, there is a long downturn in prices throughout the 1870s driven by the accumulated effects of negative commodity demand shocks during the first—but somewhat forgotten—great depression. Likewise, the early 1930s bear witness to the accumulated effects of a series of negative 
commodity demand shocks which sent real prices plummeting and which are clearly attributable to the—second—Great Depression.

After World War II, positive commodity demand shocks led to increases in real prices in the wake of the immediate post-war efforts at re-industrialization and re-urbanization in much of Europe and Japan as well as the later economic transformation of the East Asian Tigers and Japan. From 1970, negative commodity demand shocks are evident in the late 1970s, the early 1980s, and the late 1990s, respectively corresponding to the global recessions of 1974 and 1981 and the Asian financial crisis of 1997. These are followed in turn by a series of positive commodity demand shocks emerging from the late 1990s/early 2000s due to unexpectedly strong global growth, driven by the industrialization and urbanization of China. Finally, the lingering effects of the Global Financial Crisis are also clearly visible in the series for the accumulated effects of commodity demand shocks.

The historical decompositions show that inventory or commodity-specific demand shocks also play an important role in driving fluctuations in real commodity prices, particularly in the short- to medium-run. For the most part, this type of shock follows idiosyncratic patterns across the examined commodities. Detailed historical accounts for base-metal markets provide evidence that this type of shock can also be attributed more often than not to changes in inventories by cartels, governments, and/or private firms (Stuermer, 2016). However, as this demand shock is, in fact, a residual term, it might also be explained by unexpected changes in the demand for specific commodities. For example, the United States introduced the copper-plated zinc penny in the 1980s which unexpectedly drove up the real price for zinc. Such events are naturally captured by this residual demand term. 
In marked contrast, the accumulated effects of commodity supply shocks do not play an important role in driving deviations in long-run real prices from their underlying trend for most of the commodities under consideration. Generally, this type of shock is idiosyncratic in the timing of its effects and only has a transient effect on real prices. That is, they only drive shortrun fluctuations. However, there are two exceptions: commodity supply shocks dominate the formation of sugar prices and it is the second most important driver for tin prices as mentioned previously. Fairly ready explanations for these phenomena are the strong oligopolistic structure of the two markets and their long history of government intervention (c.f., Stuermer, 2014 and United States Department of Agriculture, 1971). Thus, tin has been the only base-metal market in which cartel action and international commodity agreements have prevailed for extended periods of time while sugar also has a strong history of government intervention via cartel action, international commodity agreements, and especially tariffs.

The results for the different commodities show that commodity price dynamics have basically been driven by commodity demand shocks and inventory or commodity-specific demand shocks. These two types of shock, thus, cause an appreciable portion of the medium- and long-run fluctuations in real commodity prices. Conversely, commodity supply shocks play a rather secondary and transient role. This result is fairly consistent across agricultural, mineral, and soft commodities alike with two notable exceptions (sugar and tin) which are both strongly affected by supply shocks.

\section{Conclusions and Future Prospects}

This paper is the first in providing evidence on the drivers of real commodity prices in the long-run. To this end, we assemble a new data set on the level of price and production for 12 
commodities, spanning the categories of agricultural, metal, and soft commodities from 1870 to 2013. Our results indicate that demand shocks rather than commodity supply shocks drive the majority of the fluctuation in real commodity prices. That is, commodity price booms and busts primarily have their origins in unanticipated changes in the demand for-rather than the supply of—-the set of commodities considered here.

Additionally, we find that the contribution of commodity demand shocks to real price varies across the different commodities. However, commodity demand shocks exhibit common patterns with respect to timing across the markets for agricultural, metal, and soft commodities. Inventory or commodity-specific demand shocks are the most important driver in commodity price fluctuations for most of our agricultural and soft commodities. Finally, commodity supply shocks play some role in explaining fluctuations for particular commodities, but in the main, their influence on real commodity prices is limited in impact and transitory in duration. 


\section{References}

Aghion, P. and Howitt, P. (1998), Endogenous Growth Theory. London: MIT Press.

Anderson, S.T., R. Kellogg, S. Salant (2014), “Hotelling under Pressure.” NBER Working Paper 20280.

Baumeister, C. and L. Kilian (2015), "Understanding the Decline in the Price of Oil since 2014.” Centre for Financial Studies Working Paper 501.

Bernanke, B. (2006), "Energy and the Economy. Remarks at the Economic Club of Chicago.” http://www.federalreserve.gov/boarddocs/speeches/2006/200606152/default.htm

Carter, C., Rausser, G., and Smith, A. (2011), “Commodity Booms and Busts.” Annual Review of Resource Economics, 3: 87-118.

IMF (2012), “World Economic Outlook: Growth Resuming, Dangers Remain.” Washington, D.C.: International Monetary Fund.

Groth, C. (2007), “A New Growth Perspective on Non-renewable Resources.” In Bretschger and Smulders (Ed.s), Sustainable Resource Use and Economic Dynamics. Dordrecht: Springer Netherlands, 127-163.

Irwin, S.H. (2009), "Devil or Angel? The Role of Speculation in the Recent Commodity Price Boom (and Bust).” Journal of Agricultural and Applied Economics 41(2), 377-391.

Jacks, D.S. (2013), "From Boom to Bust: A Typology of Real Commodity Prices in the Long Run.” NBER Working Paper 18874.

Kilian, L. (2008), “The Economic Effects of Energy Price Shocks.” Journal of Economic Literature 46(4): 871-909.

Kilian, L. (2009), "Not All Oil Price Shocks are Alike: Disentangling Demand and Supply Shocks in the Crude Oil Market.” American Economic Review 99(3): 1053-69.

Maddison, A. (2010), "Historical Statistics of the World Economy: 1-2008 AD. http://www.ggdc.net/maddison/

Officer, L.H. (2012), “The Annual Consumer Price Index for the United States, 1774-2011.” http://www.measuringworth.com/uscpi

Radetzki, M. (2008), A Handbook of Primary Commodities in the Global Economy. Cambridge: Cambridge University Press.

Rasmussen, T.N. and A. Roitman (2011), “Oil Shocks in a Global Perspective: Are they Really that Bad?” IMF Working Paper 11/194.

Stuermer, M. (2016), “150 Years of Boom and Bust: What Drives Mineral Commodity Prices?” Macroeconomic Dynamics, forthcoming.

Stuermer, M. (2014), “Industrialization and the Demand for Mineral Commodities.” Federal Reserve Bank of Dallas, Research Department Working Paper 1410.

Stuermer, M. and G. Schwerhoff (2013), “Technological Change in Resource Extraction and Endogenous Growth.” Bonn Econ Discussion Papers 12/2013.

Stuermer, M. and G. Schwerhoff (2015), "Non-Renewable Resources, Extraction Technology, and Endogenous Growth.” Dallas Fed Working Paper 1506.

United States Department of Agriculture (1971), “A History of Sugar Marketing.” Agricultural Economic Report 197.

Van der Ploeg, F. (2011), “Natural Resources: Curse or Blessing?” Journal of Economic Literature 49(2): 366-420.

Wellmer, F.-W. (1992), “The Concept of Lead Time.” Minerals Industry International 1005.

Yergin, D. (1991), The Prize. New York: Simon \& Schuster, Inc. 


\section{Appendix I}

This appendix details the sources of the real commodity prices and production used throughout this paper.

\section{Prices}

There are a few key sources of price data: the annual Sauerbeck/Statist (SS) series dating from 1850 to 1950; the annual Grilli and Yang (GY) series dating from 1900 to 1986; the annual unit values of mineral production provided by the United States Geographical Survey (USGS) dating from 1900; the annual Pfaffenzeller, Newbold, and Rayner (PNR) update to Grilli and Yang's series dating from 1987 to 2010; and the monthly International Monetary Fund (IMF), United Nations Conference on Trade and Development (UNCTAD), and World Bank (WB) series dating variously from 1960 and 1980 . The relevant references are:

Grilli, E.R. and M.C. Yang (1988), "Primary Commodity Prices, Manufactured Goods Prices, and the Terms of Trade of Developing Countries: What the Long Run Shows.” World Bank Economic Review 2(1): 1-47.

Pfaffenzeller, S., P. Newbold, and A. Rayner (2007), "A Short Note on Updating the Grilli and Yang Commodity Price Index.” World Bank Economic Review 21(1): 151-163.

Sauerbeck, A. (1886), "Prices of Commodities and the Precious Metals." Journal of the Statistical Society of London 49(3): 581-648.

Sauerbeck, A. (1893), "Prices of Commodities During the Last Seven Years." Journal of the Royal Statistical Society 56(2): 215-54.

Sauerbeck, A. (1908), "Prices of Commodities in 1908." Journal of the Royal Statistical Society 72(1): 68-80.

Sauerbeck, A. (1917), "Wholesale Prices of Commodities in 1916.” Journal of the Royal Statistical Society 80(2): 289-309.

The Statist (1930), "Wholesale Prices of Commodities in 1929.” Journal of the Royal Statistical Society 93(2): 271-87.

"Wholesale Prices in 1950.” Journal of the Royal Statistical Society 114(3): 408-422.

A more detailed enumeration of the sources for each individual series is as follows.

Barley: 1850-1869, SS; 1870-1959, Manthy, R.S. (1974), Natural Resource Commodities - A Century of Statistics. Baltimore and London: Johns Hopkins Press; 1960-2013, WB.

Coffee: 1850-1959, Global Financial Data; 1960-2013, WB.

Copper: 1870-2013, Stuermer (2016).

Corn: 1850-1851, Cole, A.H. (1938), Wholesale Commodity Prices in the United States, 1700-

1861: Statistical Supplement. Cambridge: Harvard University Press; 1852-1859;

Bezanson, A. (1954), Wholesale Prices in Philadelphia 1852-1896. Philadelphia:

University of Pennsylvania Press; 1860-1999, Global Financial Data; 2000-2013, United

States Department of Agriculture National Agricultural Statistics Service.

Cotton: 1850-1899, SS; 1900-1959, GY; 1960-2013, WB.

Cottonseed: 1874-1972, Manthy, R.S. (1974), Natural Resource Commodities - A Century of 
Statistics. Baltimore and London: Johns Hopkins Press; 1973-2013, National Agricultural Statistics Service.

Lead: 1870-2013, Stuermer (2016).

Rice: 1850-1899, SS; 1900-1956, GY; 1957-1979, Global Financial Data; 1980-2013, IMF.

Rye: 1850-1851, Cole, A.H. (1938), Wholesale Commodity Prices in the United States, 1700-

1861: Statistical Supplement. Cambridge: Harvard University Press; 1852-1869,

Bezanson, A. (1954), Wholesale Prices in Philadelphia 1852-1896. Philadelphia:

University of Pennsylvania Press; 1870-1970, Manthy, R.S. (1974), Natural Resource

Commodities - A Century of Statistics. Baltimore and London: Johns Hopkins Press;

1971-2013, National Agricultural Statistics Service.

Sugar: 1850-1899, SS; 1900-1959, GY; 1960-2013, WB.

Tin: 1870-2013, Stuermer (2016).

Zinc: 1870-2013, Stuermer (2016).

\section{Production}

There are a few key sources of production data: the annual FAOSTAT (FAO) series for global production dating from 1961 to 2013; the annual Mitchell (MIT) series for country-level production dating from 1870 to 2010.

The relevant references are: Food and Agricultural Administration of the United Nations Statistics, http://faostat3.fao.org/home/E; Mitchell, B.R. (2013), International Historical Statistics, 1750-2010, http://www.palgraveconnect.com/pc/archives/ihs.html.

Barley: 1870-1961, MIT; 1962-2013, FAO.

Coffee: 1890-1924, Wickizer, V.D. (1943), The World Coffee Economy. Stanford: Food Research Institute; 1925-1934, The Commodity Yearbook, Commodity Research Bureau, various years; 1935-1974, World Bank (1975), "Structure and Prospects of the World Coffee Economy.” World Bank Staff Working Paper no. 208; 1975-2013, FAO.

Copper: 1870-2013, Stuermer (2016).

Corn: 1870-1961, MIT; 1962-2013, FAO.

Cotton: 1870-1961, MIT; 1962-2013, FAO.

Cottonseed: 1870-1961, MIT; 1962-2013, FAO.

Lead: 1870-2013, Stuermer (2016).

Rice: 1870-1961, MIT; 1962-2013, FAO.

Rye: 1870-1961, MIT; 1962-2013, FAO.

Sugar: 1870-1961, MIT; 1962-2013, FAO.

Tin: 1870-2013, Stuermer (2016).

Zinc: 1870-2013, Stuermer (2016). 
Figure 1: Historical Evolution of Global GDP, 1850-2013

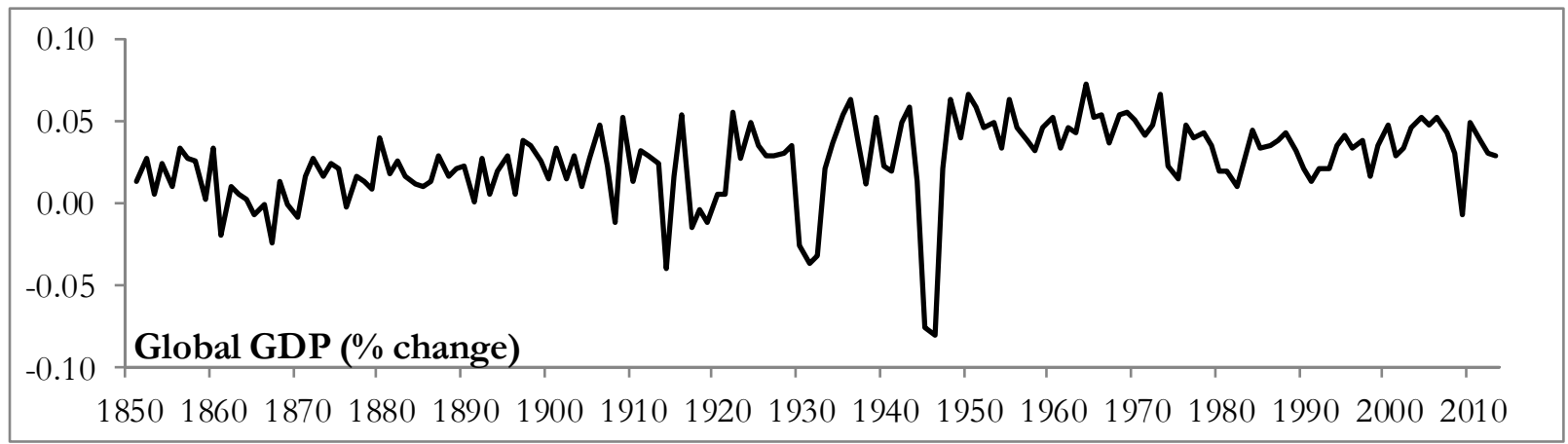

Figure 2: Historical Evolution of Grain Prices and Production
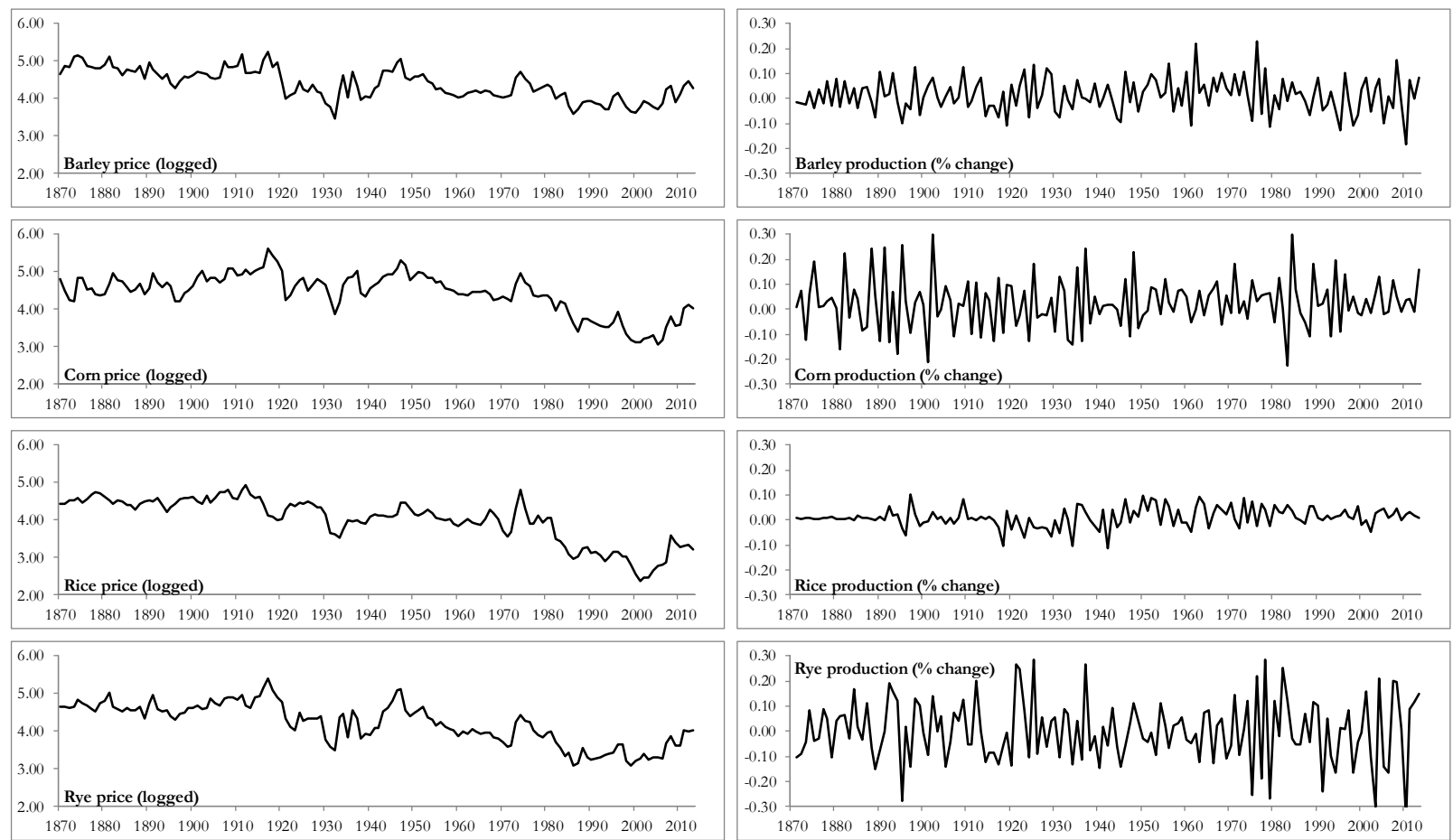
Figure 3: Historical Evolution of Metal Prices and Production

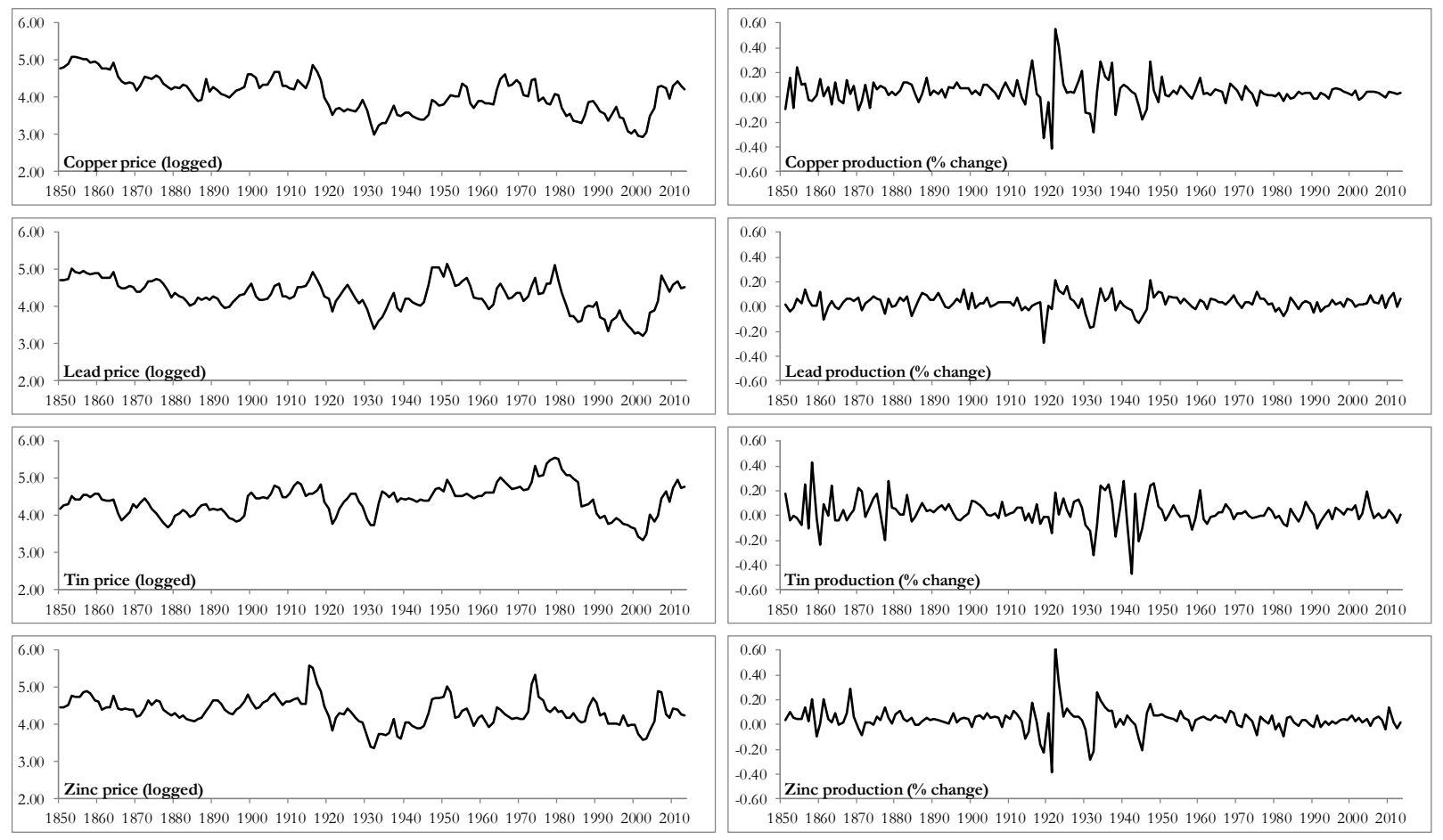


Figure 4: Historical Evolution of Soft Commodity Prices and Production

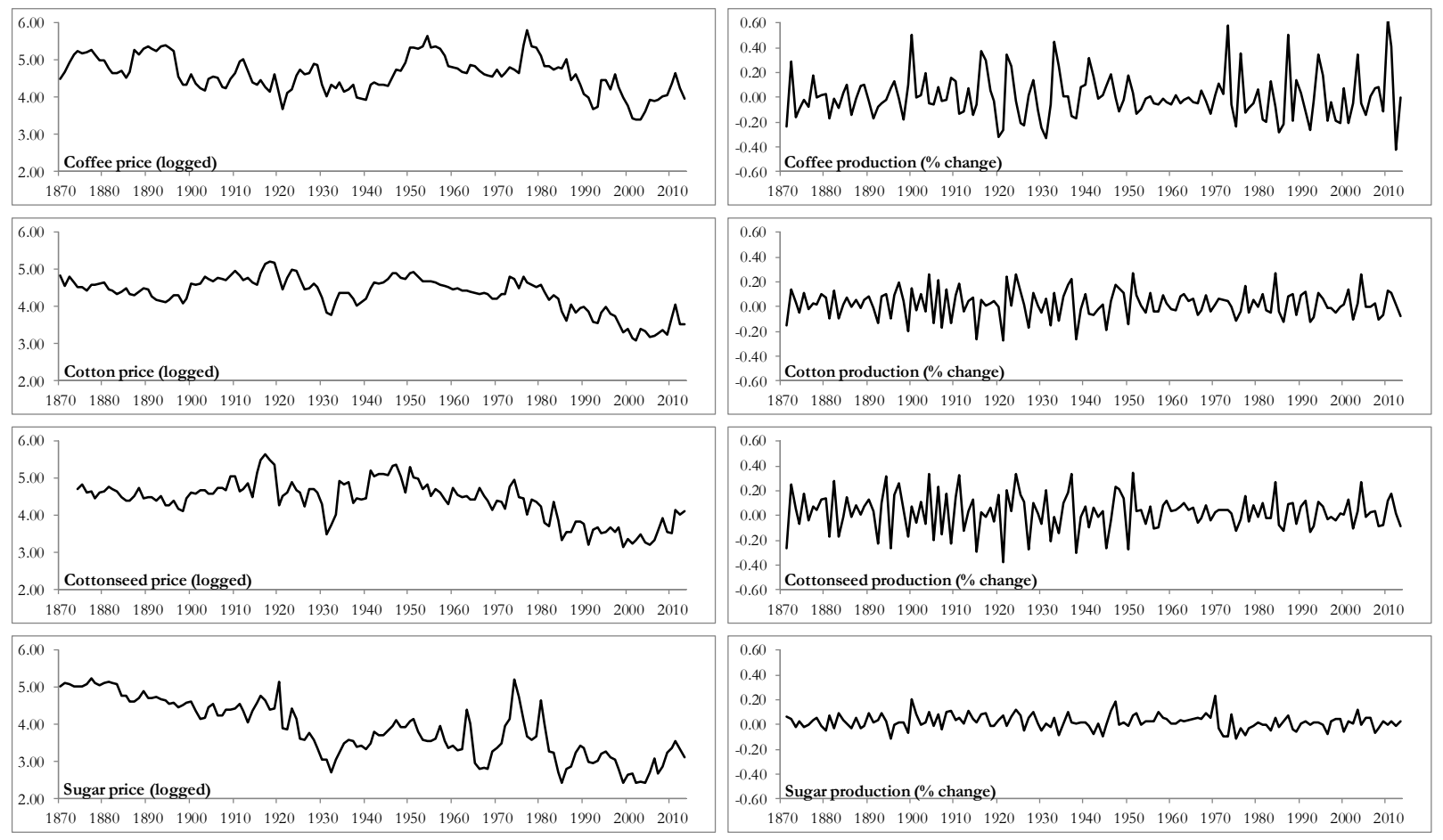


Table 1: Assumptions on Effects of Three Orthogonal Shocks on Three Endogenous Variables

\section{A. Persistent Effects}

\begin{tabular}{|l|c|c|c|}
\hline & Global GDP & Production & Price \\
\hline $\begin{array}{l}\text { Global } \\
\text { demand }\end{array}$ & YES & YES & YES \\
\hline $\begin{array}{l}\text { Commodity } \\
\text { supply }\end{array}$ & NO & YES & YES \\
\hline $\begin{array}{l}\text { Inventory or } \\
\text { other demand }\end{array}$ & NO & NO & YES \\
\hline
\end{tabular}

\section{B. Transitory Effects}

\begin{tabular}{|l|c|c|c|}
\hline & Global GDP & Production & Price \\
\hline $\begin{array}{l}\text { Global } \\
\text { demand }\end{array}$ & YES & YES & YES \\
\hline $\begin{array}{l}\text { Commodity } \\
\text { supply }\end{array}$ & YES & YES & YES \\
\hline $\begin{array}{l}\text { Inventory or } \\
\text { other demand }\end{array}$ & YES & YES & YES \\
\hline
\end{tabular}


Figure 5: Impulse Response Functions for Grains
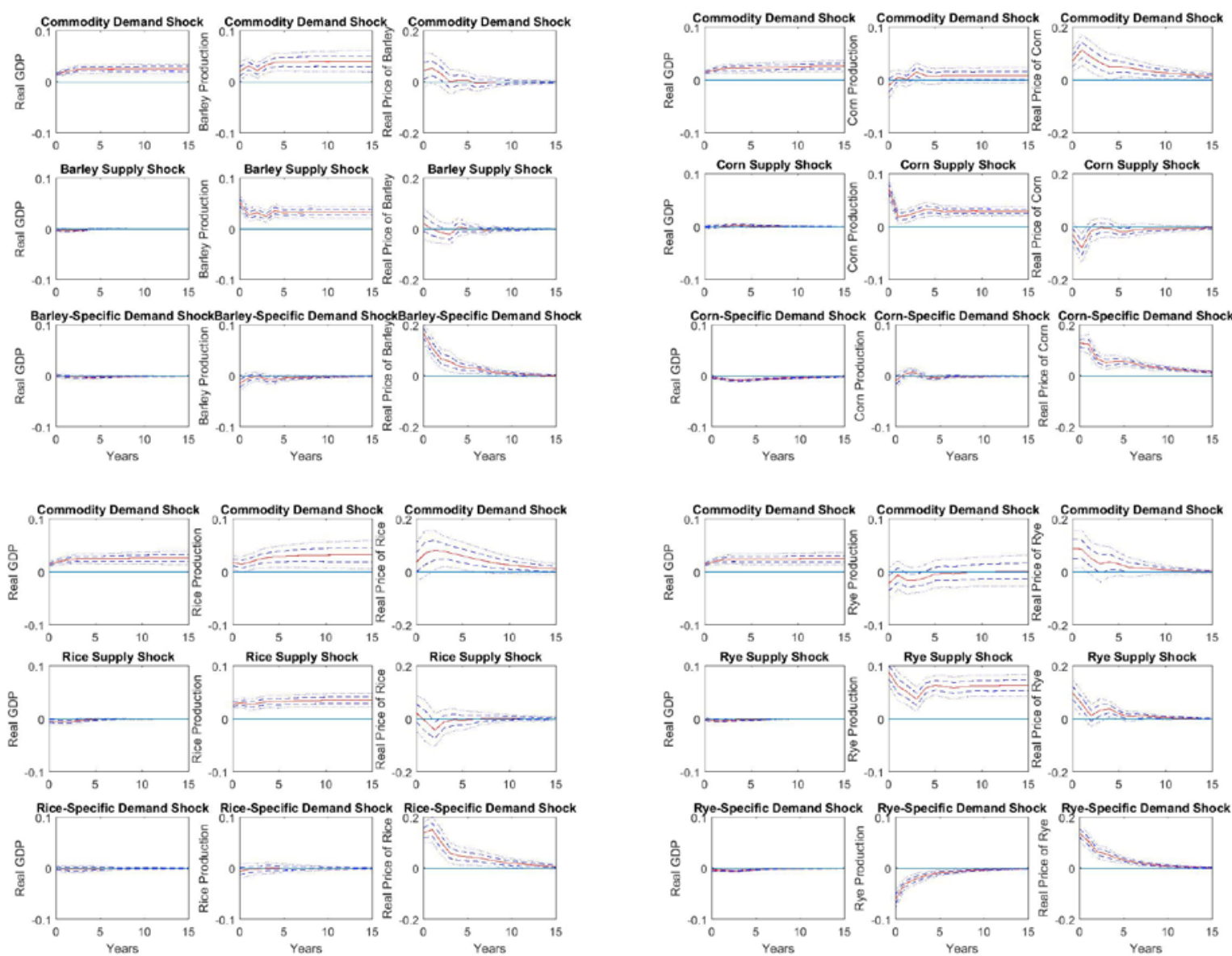
Figure 6: Impulse Response Functions for Metals
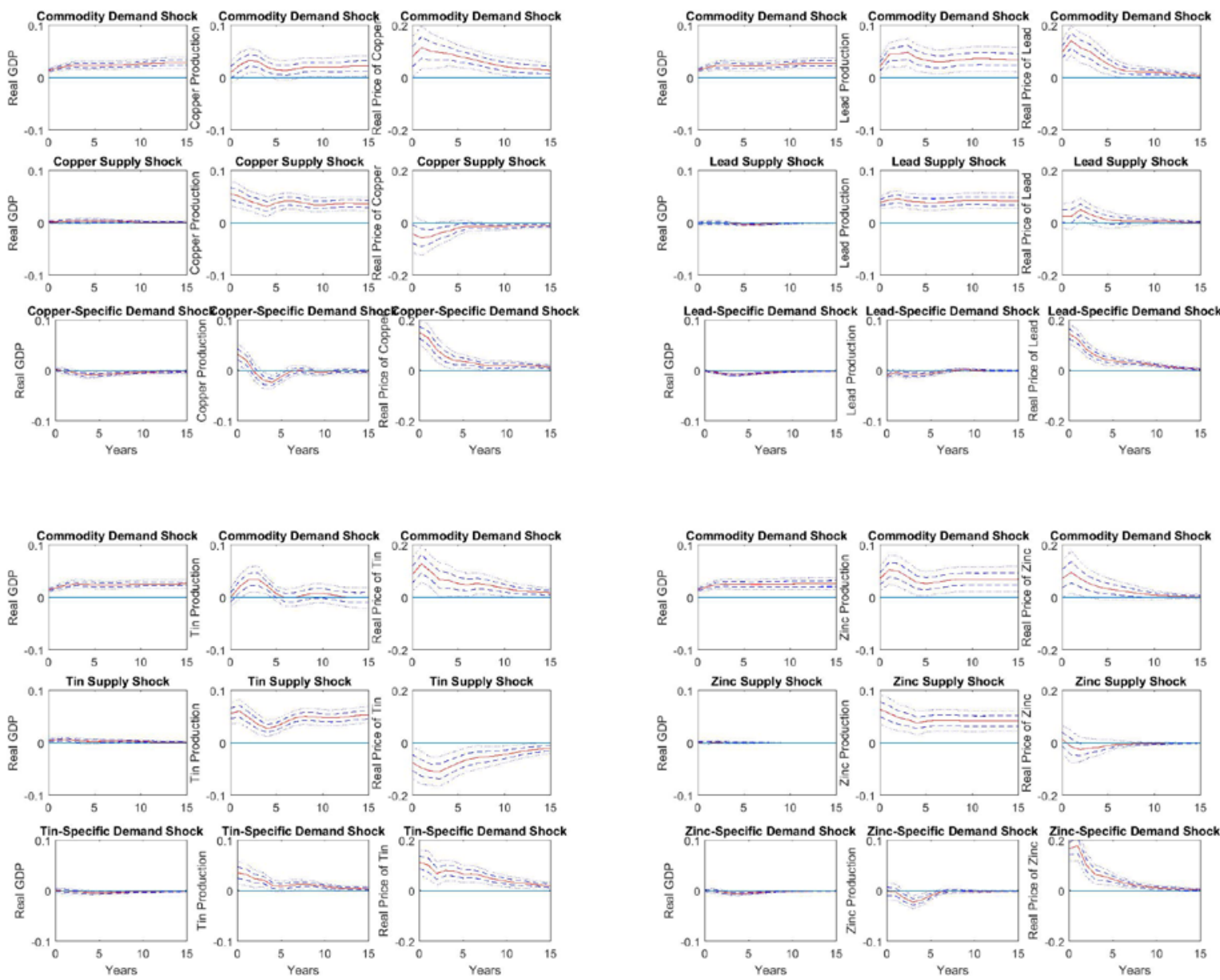
Figure 7: Impulse Response Functions for Soft Commodities
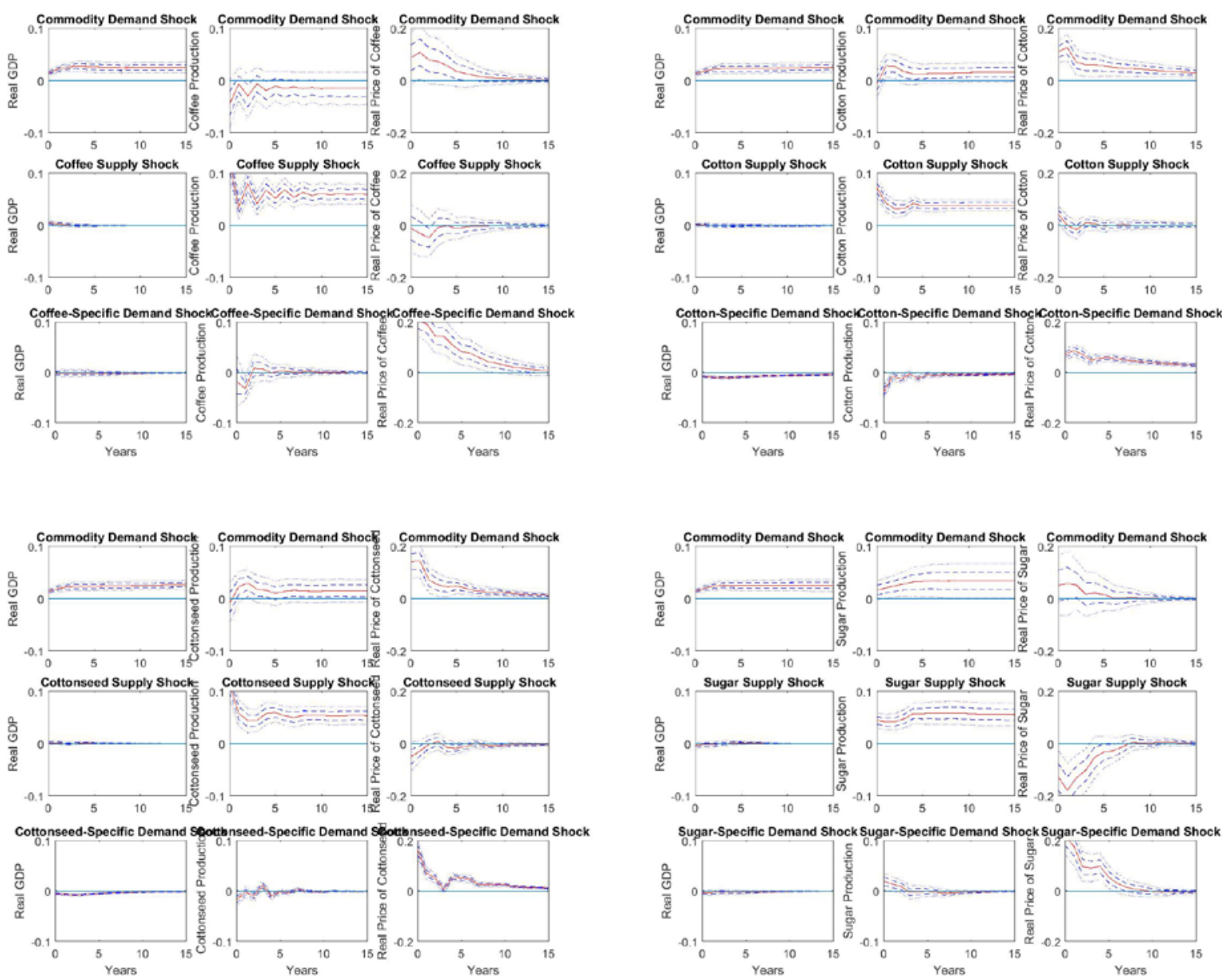

Figure 8: Historical Decompositions of Real Grain Prices 

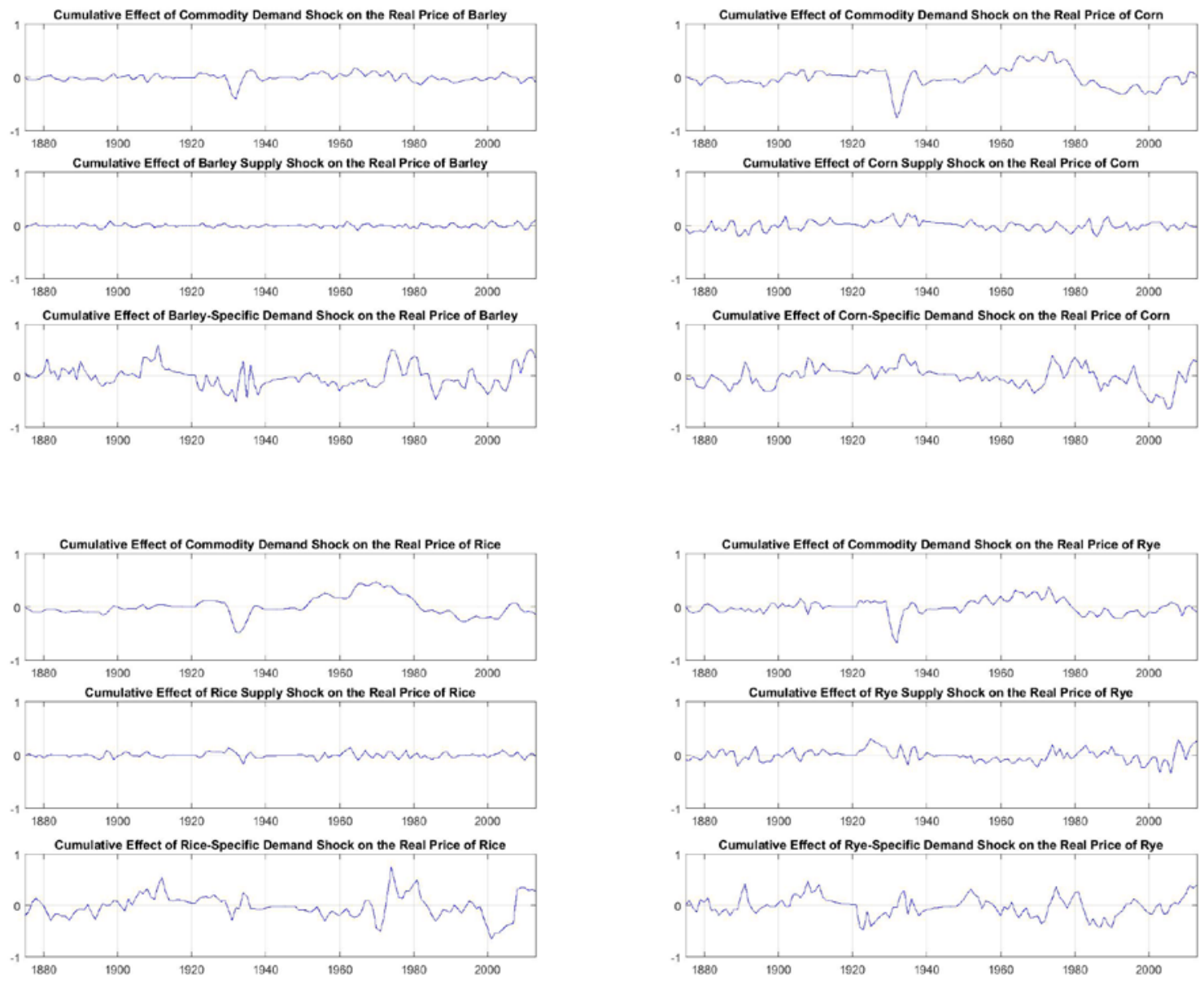
Figure 9: Historical Decompositions of Real Metal Prices
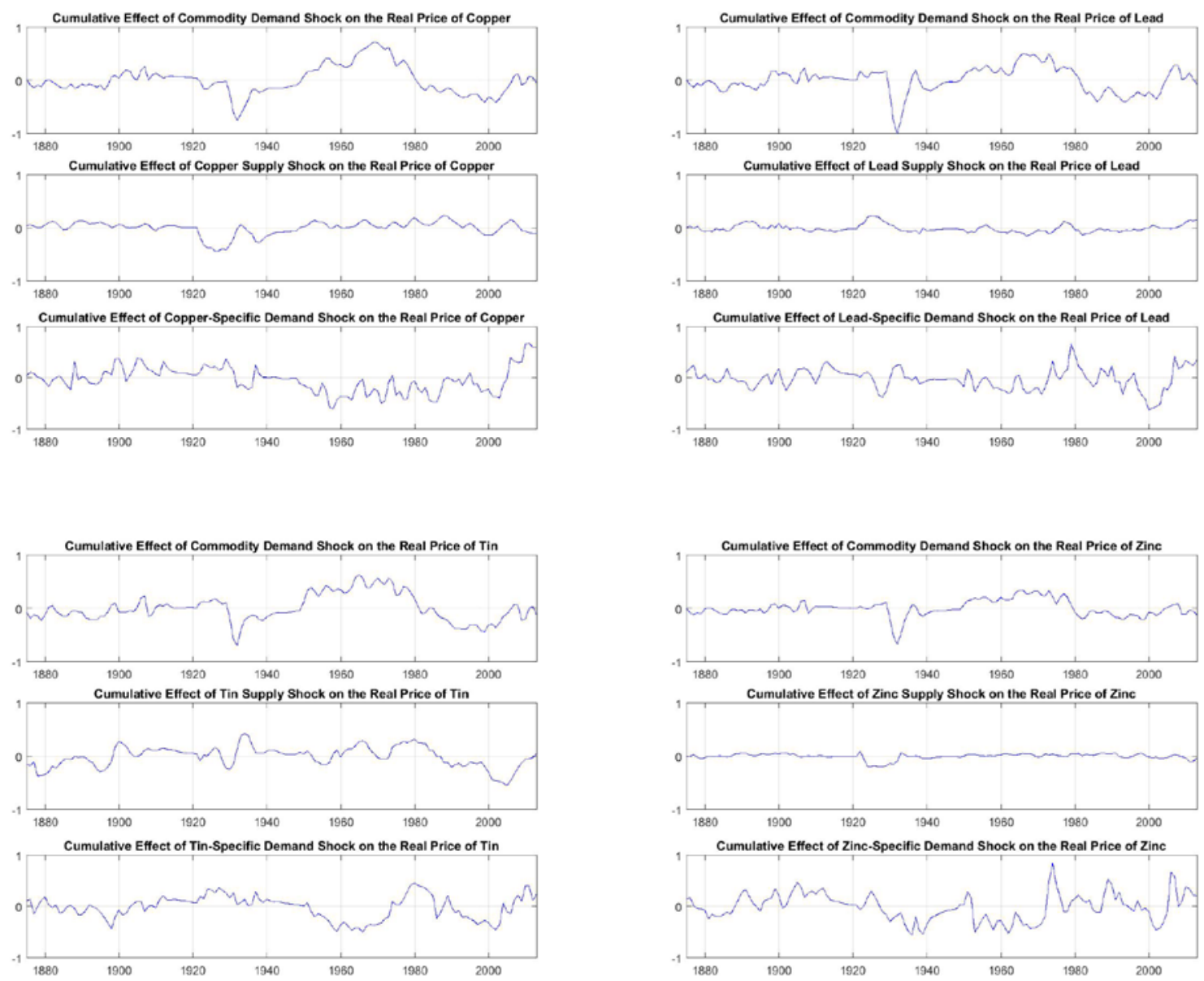


\section{Figure 10: Historical Decompositions of Real Soft Commodity Prices}
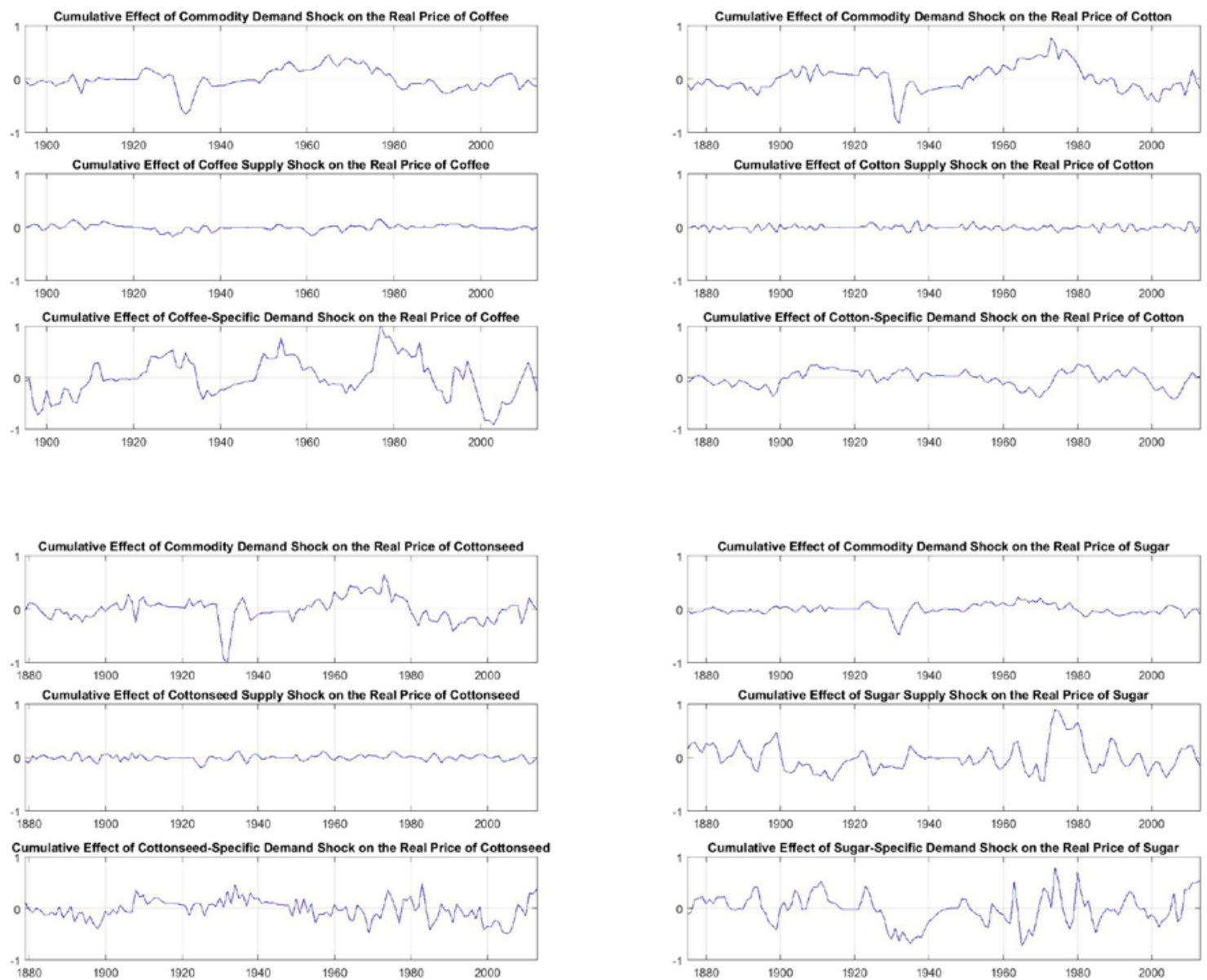